\title{
SERPINA3 Gene
}

National Cancer Institute

\section{Source}

National Cancer Institute. SERPINA3 Gene. NCI Thesaurus. Code C116577.

This gene is involved in the regulation of neutrophil cathepsin $\mathrm{G}$ and mast cell chymase activity. 